\title{
EDUCAÇÃO AMBIENTAL E INTERVENÇÃO NA MICROBACIA DO LAJEADO SABÃO, EM CONCÓRDIA-SC
}

\section{ENVIRONMENTAL EDUCATION AND INTERVENTION OF THE LAJEADO SABÃO MICROBASIN, IN CONCÓRDIA-SC}

\section{EDUCACIÓN E INTERVENCIÓN AMBIENTAL EN LA MICROBASCA DE SABÃO LAJEADO, EN CONCÓRDIA-SC}

\author{
Jairo Marchesan ${ }^{1}$ \\ Sandro Luiz Bazzanella ${ }^{2}$ \\ Maria Luiza Milani ${ }^{3}$ \\ Argos Gumbowsky ${ }^{4}$
}

\begin{abstract}
RESUMO
O objetivo deste artigo é apresentar o processo de uma experiência pedagógica ambiental desenvolvida na Escola de Educação Básica Professor Olavo Cecco Rigon, localizada na microbacia hidrográfica do Rio Lajeado Sabão, no Município de Concórdia-SC. No ano de 2016 iniciou-se o Projeto denominado "Conhecer e interagir com e na bacia hidrográfica da Escola", financiado pela Agência Nacional de Águas e Coordenação de Aperfeiçoamento de Pessoal de Ensino Superior. A metodologia adotada engloba a pesquisa-ação, aplicada exploratória, bibliográfica, de campo e qualitativa. O estudo ocorreu com duas turmas de terceiros anos do ensino médio. Dentre os resultados obtidos estão o desenvolvimento de trabalhos pedagógicos sobre o tema gerador água, sobre a implementação de práticas ou tecnologias sociais de gestão, governança e preservação das águas e sobre a produção de materiais didáticos pedagógicos. A partir da temática, a pesquisa desenvolveu a educação ambiental de forma interdisciplinar e continuada com os estudantes, voluntários, população do entorno da microbacia, além de implementar projetos de intervenções nos espaços mencionados.
\end{abstract}

Palavras-chave: Águas. Desenvolvimento Regional. Educação Básica. Meio Ambiente.

\footnotetext{
${ }^{1}$ Doutor em Geografia pela Universidade Federal de Santa Catarina (UFSC). Docente do Programa de Mestrado em Desenvolvimento Regional da Universidade do Contestado (UnC). Canoinhas. Santa Catarina. Brasil. Email: jairo@unc.br. ORCID: http://orcid.org/0000-0001-9346-0185

${ }^{2}$ Doutor em Ciências Humanas pela Universidade Federal de Santa Catarina (UFSC). Docente do Programa de Mestrado em Desenvolvimento Regional da Universidade do Contestado (UnC). Canoinhas. Santa Catarina. Brasil. E-mail: sandro@unc.br. ORCID: http://orcid.org/0000-0002-9430-8684

${ }^{3}$ Doutora em Serviço Social .Docente do Programa de Mestrado em Desenvolvimento Regional da Universidade do Contestado (UnC). Canoinhas. Santa Catarina. Brasil. E-mail: marialuiza@unc.br. ORCID: https://orcid.org/0000-0001-7588-9324.

${ }^{4}$ Doutor em Educação pela Universidade Federal do Rio Grande do Sul. Docente do Programa de Mestrado em Desenvolvimento Regional da Universidade do Contestado (UnC). Canoinhas. Santa Catarina. Brasil. E-mail: argos@unc.br. ORCID: https://orcid.org/0000-0002-7217-9025
} 


\begin{abstract}
The purpose of this article is to present the process of an environmental pedagogical experience developed at the Professor Olavo Cecco Rigon Basic Education School, located in the hydrographic watershed of the Rio Lajeado Sabão, in the municipality of Concórdia-SC. In 2016, the project entitled "Knowing and interacting with and in the School's watershed" started, financed by the National Water Agency and the Higher Education Personnel Improvement Coordination. The methodology adopted includes action research, applied exploratory, bibliographic, field and qualitative. Among the results obtained are the development of pedagogical works on the theme of water generation, on the implementation of practices or social technologies for water management, governance and preservation and on the production of educational teaching materials. Based on the theme, the research developed environmental education in an interdisciplinary and continuous way with students, volunteers, the population surrounding the watershed, in addition to implementing intervention projects in the spaces mentioned.
\end{abstract}

Keywords: Waters. Regional Development. Basic Education. Environment.

\title{
RESUMEN
}

El propósito de este artículo es presentar el proceso de una experiencia pedagógica ambiental desarrollada en la Escuela de Educación Básica del Profesor Olavo Cecco Rigon, ubicada en la cuenca hidrográfica del río Lajeado Sabão, en el municipio de Concórdia-SC. En 2016, comenzó el proyecto denominado "Conocer e interactuar con y en la cuenca de la escuela", financiado por la Agencia Nacional del Agua y la Coordinación de Mejoramiento del Personal de Educación Superior. El estudio se realizó con dos clases de tercer año de secundaria. Entre los resultados obtenidos se encuentran el desarrollo de trabajos pedagógicos sobre el tema de la generación de agua, sobre la implementación de prácticas o tecnologías sociales para la gestión, gobernabilidad y preservación del agua y sobre la producción de materiales didácticos educativos. Con base en el tema, la investigación desarrolló la educación ambiental de manera interdisciplinaria y continua para estudiantes, voluntarios, la población que rodea la cuenca, además de implementar proyectos de intervención en los espacios mencionados.

Palavras clave: Aguas. Desarrollo Regional. Educación Básica. Medio Ambiente.

Como citar este artigo: MARCHESAN, Jairo et al. Educação ambiental e intervenção na microbacia do Lajeado Sabão, em Concórdia-SC. DRd - Desenvolvimento Regional em debate, v. 10, p. 1235-1257, 29 out. 2020. DOI: https://doi.org/10.24302/drd.v10i0.3013

Artigo recebido em: 20/07/2020

Artigo aprovado em: 30/09/2020

Artigo publicado em: 29/10/2020 


\section{INTRODUÇÃO}

Os problemas econômicos e sociais que envolvem a sociedade humana contemporânea, especialmente os ambientais, e mais especificamente os que se relacionam com às águas, são amplos, crescentes e complexos. Para entendê-los, a educação formal constitui-se como uma das possibilidades. Nesta perspectiva, a escola como instituição formal é um local privilegiado para estudar, conhecer e questionar a trajetória e a história da sociedade humana, bem como para compreender de que maneira se organiza socialmente sob o ponto de vista da produção, da economia, dos aspectos sociais, culturais, políticos e ambientais.

Ocorre que, no planeta terra, a demanda de plena produção e consumo que constitui nosso modo de vida requer crescente demanda pelo uso da água, consequentemente, isso ocasiona comprometimento de sua qualidade e quantidade. Tal fator decorre, dentre outros motivos, da forma como a sociedade está organizada. Por isso, neste contexto, é importante reconhecer como nos relacionamos com os bens naturais e discernir os preceitos do modo de produção capitalista em curso, para compreender como ele estimula a produtividade a qualquer custo, gerando a acumulação desigual, a maximização do lucro, a competitividade e a destruição do meio ambiente. Tal condição determina formas de exploração dos bens naturais, transformados, distribuídos e consumidos. E é neste contexto socioeconômico que a sociedade humana habita e estabelece relações com um dos principais bens naturais: a água.

As temáticas ambientais, especialmente aquelas que envolvem a água, são emergentes, urgentes e necessárias. É um tema considerado por muitos autores (BRASIL, 1999; MARCHESAN, 2003; DIAS, 2010; GONÇALVES, 2002; 2006; CARTA DA TERRA, 2004) das áreas ambientais, bem como de diferentes setores da sociedade, como uma das exigências fundamentais à qualidade de vida das pessoas, para ao ambiente e ao desenvolvimento regional.

Ao estudar, planejar, gerir ou intervir ambientalmente em prol das águas, uma das alternativas metodológicas reside em delimitar e atuar em nível de bacias hidrográficas. Essas que, conceitualmente, podem ser entendidas como "[...] espaço geográfico delimitado pelo respectivo divisor de águas cujo escoamento superficial converge para seu interior sendo captado pela rede de drenagem que lhe concerne" (ANA, 2014, p. 7). Ou seja, bacia hidrográfica é uma determinada área de terras ou unidades territoriais divididas topograficamente pelas partes mais altas, denominados de divisores de água ou interflúvio, sendo que toda suas águas convergem direta ou indiretamente para um rio principal, assim, pode ser considerada unidade produtora e armazenadora de água. Por vezes, e dependendo dos interesses, pode ser percebida (ou não) simplesmente como espaço para o escoamento das águas. Neste artigo, a bacia hidrográfica foi considerada como espaço de estudos e de intervenção, mas, sobretudo, como uma unidade territorial produtora, retentora e armazenadora de água. De acordo com a Lei Federal no 9.433/1997, conhecida também como a "Lei das águas", a bacia hidrográfica é um conceito utilizado por várias áreas do conhecimento como possibilidade de estudos, planejamento, gestão das águas e dos bens naturais (solos, vegetação, fauna) (BRASIL, 1997).

A bacia hidrográfica pode ser entendida como um sistema, isto é, composta pelas interrelações dos subsistemas de canais, córregos e rios, mas, também, nela ocorrem relações advindas dos sistemas sociais, políticos, econômicos, demográficos e biofísicos que interagem constantemente. Por isso, é importante que cada cidadão reconheça em qual bacia hidrográfica

DRd - Desenvolvimento Regional em debate (ISSNe 2237-9029) 
encontra-se instalado, e que suas ações, bem como as ações de sua comunidade, do modo de produção presente naquele contexto societário, repercutem de forma direta ou indireta na quantidade e na qualidade das águas do local.

As questões que envolvem o meio ambiente e a água mais especificamente, integram os denominados temas transversais ${ }^{5}$ no campo da educação, como também a Base Nacional Comum Curricular (BNCC) ${ }^{6}$ e o Currículo Base da Educação Infantil e do Ensino Fundamental do Território Catarinense ${ }^{7}$.

Nesse contexto, a educação ambiental deixa de ser pensada e executada de forma isolada ou fragmentada, para ser concebida de modo contextualizado, inter ${ }^{8}$ e multidisciplinar ${ }^{9}$. Constata-se frequentemente a ausência de textos reflexivos, materiais didáticos e pedagógicos que enfatizem a educação ambiental, assim como a falta de estudo acerca do assunto aqui salientado: a questão da relação e do uso humano das águas. Por consequência, reconhece-se a importância estratégica em elaborar material pedagógico sobre as águas com maior especificidade, seja na perspectiva da conservação de mananciais, na democratização do acesso a esse recurso em quantidade e qualidade, na consciência de que é um elemento natural coletivo e necessário às demais formas de vida.

Com isso, há o reconhecimento da necessidade de cuidar da água e usá-la parcimoniosamente, afinal, em quantidade e qualidade é uma questão humanitária, de saúde pública, e fundamentalmente de sobrevivência e reprodução da biodiversidade. Por outro lado, se circunscreve nessa linha de argumentação a importância política do acesso e cuidado com esse artifício natural em função de sua condição vital e, portanto, estratégica para sobrevivência de povos, países, comunidades, e, por extensão, pela importância econômica que os cuidados e a preservação dos recursos hídricos oportunizam em um planeta altamente competitivo.

\section{OS FUNDAMENTOS TEÓRICOS}

A problemática ambiental, tanto nos aspectos mais amplos, quanto nos mais específicos de cada país ou território local, pode propiciar reflexões sobre as relações da sociedade humana entre si e com a natureza. De maneira geral, as relações com a natureza na contemporaneidade são agressivas, e geraram uma crise ambiental que se transforma em estatal-civilizatória, conforme explicita Leff (2001, p. 150): “[...] não só se propõem limites da racionalidade

\footnotetext{
${ }^{5}$ Os temas transversais devem fazer parte das Instituições de Ensino, pois expressam conceitos e valores humanos. São constituídos pelos Parâmetros Curriculares Nacionais (PCN) e compreendem cinco áreas do conhecimento: Ética; Orientação Sexual; Meio Ambiente; Pluralidade Cultural e Trabalho e Consumo (BRASIL, 1998).

${ }^{6}$ A Base Nacional Comum Curricular foi aprovada pela Resolução no 4, de 17 de dezembro de 2018 do Conselho Nacional de Educação. O documento define os direitos de aprendizagens de todos os alunos do Brasil e é obrigatório no território nacional (BRASIL, 2018).

${ }^{7}$ O Currículo Base da Educação Infantil e do Ensino Fundamental do Território Catarinense foi aprovado pela Resolução CEE/SC n ${ }^{\circ}$ 070, de 17 de junho de 2019 do Conselho Estadual de Educação de Santa Catarina. O documento decorre da BNCC e sua adoção é obrigatória pelos estabelecimentos de ensino integrantes do Sistema Estadual de Educação a partir do ano de 2020.

${ }^{8}$ Concepção apresentada adiante no texto.

${ }^{9}$ Concepção apresentada adiante no texto.
}

DRd - Desenvolvimento Regional em debate (ISSNe 2237-9029)

v. 10, p. 1235-1257, 2020. 
econômica, mas também a crise do Estado, de uma crise de legitimidade de suas instâncias de representação de onde emerge uma sociedade civil em busca de um novo paradigma civilizatório".

Dias (2010) argumenta que os estudos do ambiente devem considerar as dimensões abrangentes, incorporando aspectos sociais, culturais e econômicos. A compreensão de ambiente se expressa na esfera das concepções, atitudes, ações, práticas, comportamentos e necessidades humanas. De modo geral, é o espaço onde se materializam as ações e interações, sejam elas entre indivíduos da mesma espécie ou de espécies diferentes, as quais, através do tempo, se relacionam, criando novas configurações naturais e culturais.

O sentido e o significado de ambiente constituem-se a partir das interações dos sujeitos do processo de organização social em determinado local. Afinal, a apropriação dos recursos naturais ocorre de acordo com os interesses privados e coletivos. Isso representa muito mais do que a simples divergência de visões, pois o que está em jogo é a maneira de apropriar-se dos bens naturais e utilizá-los. "Portanto, qualquer intervenção no ciclo natural da água deve ser cautelosa e regulada com grande precisão. Os rios são as veias do sistema; qualquer intervenção que eles sofrem gera, inevitavelmente, mudanças neste"10 (RUIZ; RODRÍGUEZ, 2020, p. 49).

Assim, a escola, por ser uma instituição social, é um espaço privilegiado para pensar, propor e agir na perspectiva da construção, reprodução e aplicação de conhecimentos. Além dela, importam também os professores, visto que são atores e agentes interativos do processo formativo e educativo. Neste contexto, é imprescindível estimular os estudantes a analisar as relações e contradições sociais e humanas com a natureza em sua totalidade, considerando o tempo e espaço.

É fundamental que se considere a educação ambiental em sua dimensão formal e informal, convergindo para aprendizagens, atitudes, valores e ações ecologicamente mais equilibrados. Isso pode ocorrer nas relações pessoais e interpessoais, promovidas a partir das reflexões consigo e com os outros, bem como com o meio ambiente. Por isso, há a necessidade de estabelecermos ênfase nas práticas e experiências pessoais e, principalmente, coletivas. Afirma Nidelcoff (1986, p. 06) que: "[...] o papel do professor é ajudar as crianças [educandos] a: ver, compreender a realidade; expressar a realidade, expressar-se; descobrir, assumir a responsabilidade de ser elemento de mudança na realidade". Sob essa abordagem, recorre-se à Política Nacional de Educação Ambiental, exteriorizada pela Lei Federal no 9.795, de 27 de abril de 1999, a qual, em seu Art. $1^{\circ}$, estabelece que

Entende-se por educação ambiental os processos por meio dos quais o indivíduo e a coletividade constroem valores sociais, conhecimentos, habilidades, atitudes e competências voltadas para a conservação do meio ambiente, bem de uso comum do povo, essencial à sadia qualidade de vida e sua sustentabilidade (BRASI, 1999, art. 1).

A educação ambiental não formal é igualmente importante e complexa por ser uma ação catalítica, de certa forma paralela à escola nas questões comunitárias. Conforme o Art. 13 da citada lei, ao referir-se sobre a educação não formal:

\footnotetext{
10 "Por tanto, debe cautelarse y regularse con mucha precisión cualquier intervención sobre el ciclo natural del agua. Los ríos son las venas del sistema; cualquier intervención que sufran genera, irremediablemente, cambios en este” (RUIZ; RODRÍGUEZ, 2020, p. 49).
} 
"Entende-se por educação ambiental não formal as ações e práticas educativas voltadas à sensibilização da coletividade sobre as questões ambientais e à sua organização e participação na defesa da qualidade do meio ambiente" (BRASIL, 1999, art. 13).

Dessa forma, urge ampliar a dimensão educativa ambiental para além da educação formal instituída, principalmente da escola. Para tanto, se justifica a importância e o papel dos comitês de bacia, conforme estabelece a Lei Federal 9.433/97 (BRASIL, 1997) de fomento ao envolvimento e ao compromisso social de todas as instâncias do poder político (municipal, estadual e federal) dos segmentos sociais, sejam eles públicos ou privados. As iniciativas devem ir ao encontro do desenvolvimento coletivo das relações pedagógicas e ações concretas na área das bacias hidrográficas, na perspectiva de gerir adequadamente os bens naturais de modo a oferecer água em quantidade e qualidade para todos.

A construção de relações mais sustentáveis com as águas exige mobilização social, participação comunitária, gestão descentralizada e participativa, de acordo com os fundamentos da Lei das Águas (BRASIL, 1997). A BNCC (BRASIL, 2018) e o Currículo Base da Educação Infantil e do Ensino Fundamental do Território Catarinense (SANTA CATARINA, 2019) definem as habilidades desejadas a serem desenvolvidas quando abordada a temática dos recursos hídricos, quais sejam:

\footnotetext{
- Investigar a importância da água e da luz para a manutenção da vida de plantas em geral. (Ensino fundamental $/ 2^{\circ}$ ano/Ciência/Habilidade 05 - EF02CI05)

- Aplicar os conhecimentos sobre as mudanças de estado físico da água para explicar o ciclo hidrológico e analisar suas implicações na agricultura, no clima, na geração de energia elétrica, no provimento de água potável e no equilíbrio dos ecossistemas regionais (ou locais). (Ensino fundamental $/ 5^{\circ}$ ano/Ciência/Habilidade 02 - EF05CI02) - Identificar os principais usos da água e de outros materiais nas atividades cotidianas para discutir e propor formas sustentáveis de utilização desses recursos. (Ensino fundamental $/ 5^{\circ}$ ano/Ciência/Habilidade 04 - EF05CI04)

- Investigar os usos dos recursos naturais, com destaque para os usos da água em atividades cotidianas (alimentação, higiene, cultivo de plantas etc.), e discutir os problemas ambientais provocados por esses usos. (Ensino fundamental $/ 3^{\circ}$ ano/Geografia/Habilidade 09 - EF03GE09)

- Identificar os cuidados necessários para utilização da água na agricultura e na geração de energia de modo a garantir a manutenção do provimento de água potável. (Ensino fundamental $/ 3^{\circ}$ ano/Geografia/Habilidade 10 - 09EF03GE10)

- Reconhecer e comparar atributos da qualidade ambiental e algumas formas de poluição dos cursos de água e dos oceanos (esgotos, efluentes industriais, marés negras etc.). (Ensino fundamental $/ 5^{\circ}$ ano/Geografia/Habilidade10 - EF05GE10) - Descrever o ciclo da água, comparando o escoamento superficial no ambiente urbano e rural, reconhecendo os principais componentes da morfologia das bacias e das redes hidrográficas e a sua localização no modelado da superfície terrestre e da cobertura vegetal. (Ensino fundamental $/ 6^{\circ}$ ano/Geografia/Habilidade 04 - EF06GE04) - Analisar a importância dos principais recursos hídricos da América Latina (Aquífero Guarani, Bacias do rio da Prata, do Amazonas e do Orinoco, sistemas de nuvens na Amazônia e nos Andes, entre outros) e discutir os desafios relacionados à gestão e comercialização da água. (Ensino fundamental $/ 8^{\circ}$ ano/Geografia/Habilidade 15 EF08GE15 (BRASIL, 2018).
}

A partir dessas bases, faz-se necessário construir coletivamente um projeto pedagógico escolar que contemple a educação ambiental em suas dimensões teóricas e práticas de forma contínua, sistemática e duradoura, o que seguramente se apresenta como um belo desafio educacional. Iniciativas dessa envergadura passam por contínuos e necessários processos de formação e reflexão. Para além dessa condição, esse projeto deverá ser contemplado no Plano

DRd - Desenvolvimento Regional em debate (ISSNe 2237-9029) 
Político Pedagógico da Escola e assumido como compromisso pelo coletivo dos professores e demais integrantes da Comunidade Escolar. Complementa Florêncio (2018, p. 69-70) que:

Diante da complexa situação (implementação da BNCC e Reforma do ensino médio)
da educação brasileira, a excursão pedagógica constitui uma alternativa ao
desenvolvimento de ações que procura analisar os fenômenos a partir da integração
dos diferentes componentes curriculares. Destaca-se a oportunidade que a excursão
pedagógica fornece para a associação dos conteúdos curriculares a partir da
valorização do contexto local do discente.

Também, é fundamental partir do pressuposto de que o espaço escolar pode e deve propiciar estratégias e possibilidades para ampliar e aprofundar o entendimento das questões socioambientais a partir das condições locais. Isso exige reflexões e práticas educativas mediadas pelo diálogo, pelo respeito, pelo compromisso e pela autonomia dos sujeitos. Nessa perspectiva, torna-se relevante eleger coletivamente conteúdos significativos, dentre os quais estejam presentes assuntos ou temas que envolvam o cotidiano da vida dos sujeitos.

A construção da proposta da educação ambiental emancipatória incorpora valores que imprimem outros sentidos ao exercício da cidadania, entre eles: compreender a necessidade premente de adequação à natureza, entender e reconhecer que o ser humano pode adequar-se à natureza e não a natureza se adequar aos desejos sistemáticos da sociedade humana. Segundo Quintas (2019, p. 20), diz que

[...] a Constituição Federal brasileira estabeleceu, pela primeira vez na história do país, um conjunto de salvaguardas configuradas em direitos individuais, coletivos e sociais. Entre esses direitos está o direito a um 'ambiente ecologicamente equilibrado' no artigo 225 , considerado um 'bem de uso comum essencial para uma qualidade de vida saudável'11.

Nesta sequência, tornam-se muito frequentes discussões sobre as relações da sociedade humana com a natureza. De maneira geral, é preciso reconhecer que a forma como a sociedade está organizada social, política e economicamente gera significativos problemas ambientais. Nessa direção, o ser humano, de maneira geral, caracteriza-se como predador e saqueador da natureza. Afinal, predominam as concepções e práticas do antropocentrismo. Ou seja, o ser humano considera-se como ser "superior" e dominador da natureza.

Sob tais pressupostos é possível compreender de forma profunda as relações entre o ser humano e seu meio natural, e a conexão com a construção e o fortalecimento da cidadania por meio do processo educativo. Afinal, cidadania "[...] implica a posse de direitos civis, políticos e sociais" (LEONARDI, 2001, p. 250). E deve possibilitar a aquisição de conhecimentos, valores e atitudes que viabilizem relações de cuidados ambientais.

As ações educativas, sejam formais ou não formais, devem estar estruturadas com vistas ao desenvolvimento de atitudes, valores e comportamentos sociais favoráveis ao meio ambiente. Devem, também, possibilitar o fortalecimento do processo de construção da cidadania, organização social e comunitária, na perspectiva da sustentabilidade.

\footnotetext{
11“La Constitution fédérale brésilienne a établi, pour la première fois au cours de l'histoire du pays, un ensemble de garanties configurées en droits individuels, collectifs et sociaux. Parmi ces droits, figure, dans l'article 225, le droit à un "environnement écologiquement équilibré» qui est considéré comme un "bien à usage commun et essentiel à une saine qualité de la vie»" (QUINTAS, 2019, p. 20).
} 
O Tratado de Educação Ambiental para Sociedades Sustentáveis e Responsabilidade Global $^{12}$ propõe que a educação ambiental para uma sustentabilidade equitativa, constitua-se em um processo de aprendizagem permanente, amparado no respeito a todas as formas de vida, que defina valores e ações capazes de contribuir à transformação humana, social e à preservação ecológica. A educação ambiental pode estimular a atuação na perspectiva da formação de sociedades mais justas e ecologicamente equilibradas, que conservem entre si relações de interdependência e diversidade. Isso requer responsabilidade individual e coletiva em nível local, nacional e planetário (VIEZZER; OVALLES, 1994, p. 29).

Também, de acordo com Dias (2010), as dimensões socioculturais e econômicas definem as orientações e os instrumentos conceituais e técnicos com os quais o ser humano poderá compreender e utilizar melhor os bens naturais para satisfazer as suas necessidades. Todo esse processo exige compromissos individuais e coletivos, em função da promoção do desenvolvimento de práticas cotidianas sustentáveis ambientalmente.

\section{PERSPECTIVAS METODOLÓGICAS}

A escola representa um dos espaços para a formação humana integral refletir e propor ações com o objetivo de melhorar as relações da sociedade humana entre si e dessa com o ambiente. Afinal, é na escola que estão as futuras gerações, os adolescentes, os jovens, esses que possuem potencial de desenvolvimento do pensamento, de possibilidades do protagonismo da participação e da ação.

Nessa perspectiva, a partir do ano de 2010, a Escola de Educação Básica Professor Olavo Cecco Rigon, integrante da rede Pública Estadual de Santa Catarina, localizada no município de Concórdia-SC (Figura 01), buscou articular os conhecimentos científicos as experiências de vida para melhor conhecer e compreender a realidade ambiental regional, mais especificamente das águas.

\footnotetext{
${ }^{12} \mathrm{O}$ Tratado de Educação Ambiental para Sociedades Sustentáveis e Responsabilidade Global ocorreu no Rio de Janeiro, em 1992 durante a Rio 92. É um documento que constitui marco referencial da Educação Ambiental. Tornou-se a Carta de Princípios da Rede Brasileira de Educação Ambiental, e das demais redes de EA a ela entrelaçadas.
} 
Figura 01 - Figura de localização da microbacia do Lajeado Sabão no município de Concórdia-SC e da Escola de Educação Básica Professor Olavo Cecco Rigon.

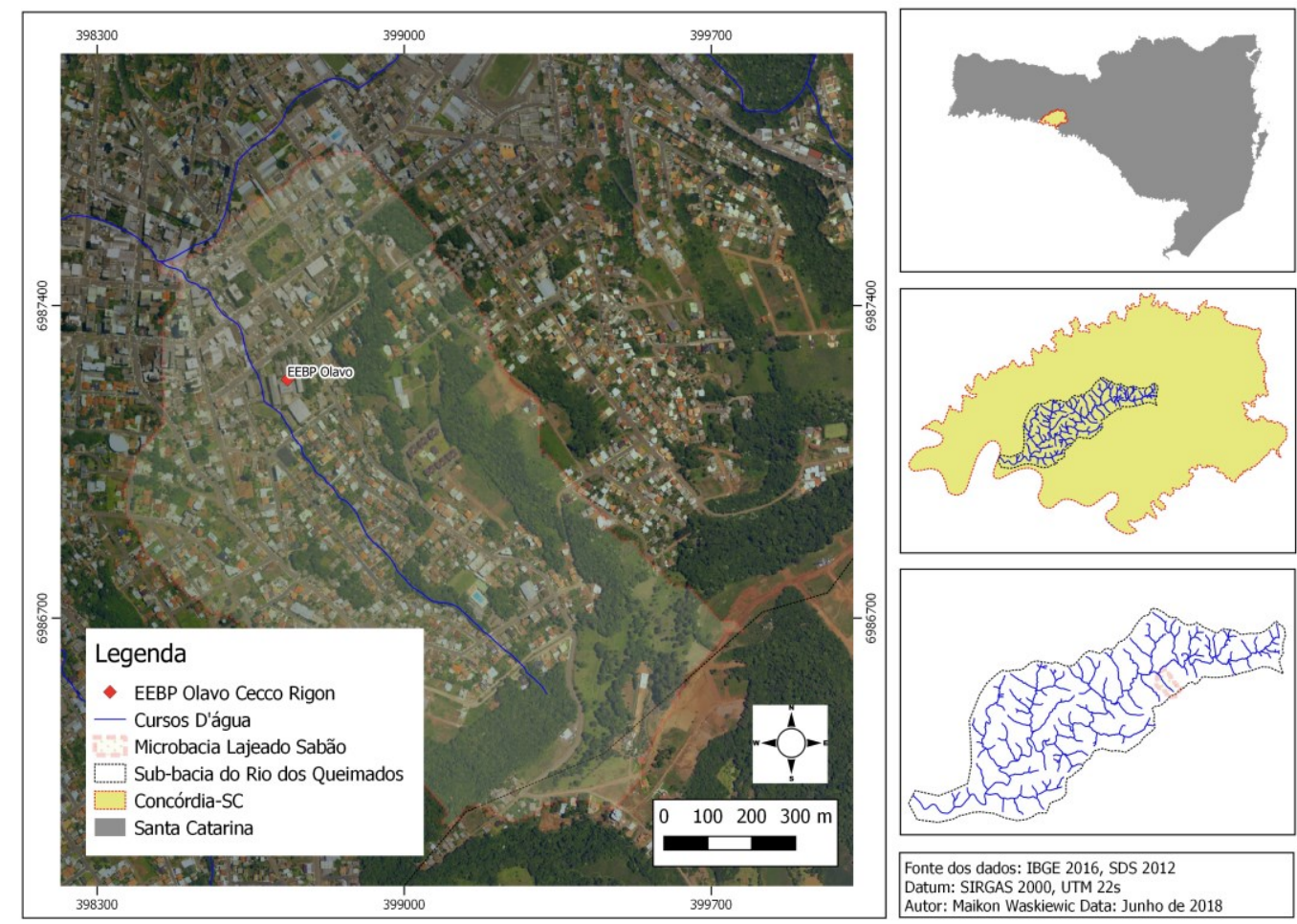

Fonte: Waskiewic (2018).

Amparada no Projeto Político Pedagógico (PPP), a Escola desenvolveu projetos de intervenção na área ambiental. Nessa direção, incentivou nos estudantes a criatividade da inovação e o desenvolvimento de tecnologias sociais para a gestão ambiental e das águas no entorno dos espaços da escola e imediações, como por exemplo, na microbacia do Lajeado Sabão. Tais ações e intervenções possibilitaram que os estudantes compreendessem as relações da sociedade humana com o ambiente no tempo e no espaço.

De igual modo, a Escola de Educação Básica Professor Olavo Cecco Rigon destaca-se no seu percurso histórico por contemplar em seu PPP ações que promovem o trabalho coletivo, discussões, proposições e intervenções em prol das questões ambientais. Por consequência, a partir do ano letivo de 2010 principalmente, em função dos fenômenos climáticos globais e locais que envolveram as questões ambientais, por exemplo, os períodos de estiagem, a escola atuou com mais intensidade na temática de recursos hídricos. Afinal, não há desenvolvimento socioeconômico e qualidade de vida ambiental se não houver água em quantidade e qualidade.

Nessa perspectiva instituiu-se um projeto para conhecer a história do Rio Lajeado Sabão, o qual passa no terreno escolar. Além disso, o projeto contemplava possibilidades de intervenção no sentido de contribuir para a revitalização do rio. Para isso, desenvolveram-se pesquisas, trabalhos pedagógicos, teóricos e práticos, realizaram-se caminhadas no entorno e ao longo do rio e da bacia hidrográfica em que a escola está inserida, dentre outras atividades.

No ano de 2015, a Agência Nacional de Águas (ANA) e a Coordenação de Aperfeiçoamento de Pessoal de Ensino Superior (CAPES) lançaram o Edital no 18/2015 com a 
intenção de produção de material didático pedagógico para a Educação Básica brasileira. $\mathrm{O}$ objetivo geral do mesmo consistiu em,

[...] selecionar projetos que tenham como objeto a produção de material didático sobre o tema Água, que contribuam para o processo de ensino/aprendizagem e para o desenvolvimento de conteúdos educacionais para uso nas escolas de educação básica, no Ensino Fundamental II e no Ensino Médio (CAPES, 2015, p. 1).

Ciente do teor do Edital, o Programa de Mestrado em Desenvolvimento Regional ${ }^{13}$ da Universidade do Contestado (UnC), em parceria com a referida Escola, desenvolveu a proposta em forma de Projeto, denominado: "Conhecer e interagir com e na bacia hidrográfica da Escola". Após a submissão e avaliação pelos órgãos de fomento, o projeto foi aprovado juntamente com outras dezenove propostas por Instituições de Ensino Superior de diferentes regiões do Brasil. A instituição escolar, juntamente com os professores do Programa de Mestrado em Desenvolvimento Regional, e com o apoio de ambientalistas voluntários do município de Concórdia-SC, articularam a execução do projeto. Inicialmente, houve amplo processo de mobilização; estudos teóricos sobre os conceitos de educação ambiental; desenvolvimento regional e territorial; estudos sobre bacia hidrográfica; sobre tecnologias sociais para gestão ambiental, dentre outros, resultando em reuniões, debates e reflexões. $\mathrm{O}$ Projeto foi executado a partir do ano $2016 \mathrm{com}$ uma turma do terceiro ano do Ensino Médio e uma turma do segundo ano do Ensino Médio Inovador ${ }^{14}$.

O desenvolvimento do projeto demonstrou capacidade de mobilização e sensibilização, motivando e incentivando os estudantes a se sentirem protagonistas e corresponsáveis pelo espaço onde estudam, vivem e convivem.

Da mesma forma, o protagonismo estudantil se efetivou quando os estudantes passaram a utilizar as ferramentas tecnológicas disponíveis (celulares, tablets, câmeras fotográficas, computadores e outros) para o processo de produção de material didático-pedagógico. Utilizouse o conceito de ações práticas na Bacia hidrográfica onde a Escola está situada.

É importante salientar a relevância ANA, que em parceria com a CAPES, propôs o edital para o fomento, para o debate e para a produção de material didático para as Escolas de Educação Básica, com o intuito, sobretudo, de possibilitar intensos debates, e enfatizar a educação ambiental de forma interdisciplinar e multidisciplinar.

O lançamento do Edital foi importante e estratégico na perspectiva de propiciar a constituição de novas consciências e práticas ambientais. Nesse prisma, a implementação do projeto, além de produzir materiais pedagógicos de forma interdisciplinar para os estudantes da Educação Básica, também foi instrumento utilizado por cidadãos comprometidos com as urgências das causas ambientais regionais. Ou seja, muitas experiências foram e são potenciais para serem difundidas e replicadas na sociedade.

\footnotetext{
${ }^{13}$ O Programa stricto sensu em Desenvolvimento Regional é ofertado pela Universidade do Contestado (UnC) no Campus do município de Canoinhas. A UnC possui Campus desde o Planalto Norte até o Meio Oeste Catarinense. De origem comunitária, completa, no ano de 2020, 50 anos de criação tendo como um dos seus principais compromissos o desenvolvimento regional.

${ }^{14}$ Ensino Médio Inovador é uma proposta e ação do Ministério da Educação para as escolas públicas do país. Propõe que o currículo seja mais flexível, que contemple e trabalhe os conhecimentos de forma interdisciplinar articulados à realidade dos estudantes e que atendam seus projetos de vida. A carga horária desse curso é maior que o Ensino Médio regular.
} 
O desenvolvimento do projeto possibilitou que as disciplinas escolares interagissem entre si de forma ampla, dialética, dialógica e contextualizada em relação aos diferentes saberes e situações. Dentre os esforços e iniciativas do projeto, o desafio foi produzir conhecimentos e materiais pedagógicos para promover a apropriação de conhecimentos pelos estudantes da Educação Básica, extensivo à sociedade local e regional.

Em síntese a pesquisa caracterizou-se quanto a natureza em aplicada. Na concepção de Fleury e Werlang (2016, p. 11), a pesquisa aplicada realiza-se em torno de problemas encontrados " [...] nas atividades das instituições, organizações, grupos ou atores sociais. Ela está empenhada na elaboração de diagnósticos, identificação de problemas e busca de soluções". Neste cenário, responde à demanda dos alunos, da escola e comunidade do entorno.

Quanto aos objetivos, é considerada exploratória à medida que se pautou em dados prioritariamente qualitativos, os pesquisadores interagiram diretamente com o fenômeno estudado, priorizaram estudos essencialmente qualitativos não tendo a preocupação com generalização de resultados para além da população estudada. Neste caso específico a experiência limitou-se a comunidade do entorno da microbacia do Lajeado Sabão.

Quanto ao procedimento de coleta dos dados assumiu contorno de pesquisa: a) de campo por ter sido realizada em ambiente de campo, não controlado; b) Estudo de caso: a pesquisa limitou-se à microbacia do Lajeado Sabão, assim, ressalta-se que os pesquisadores utilizaram como fontes de evidência documentação, registros em arquivo, entrevistas, observações diretas, observações participantes e artefatos físicos, cada qual com seus pontos fortes e fragilidades na comparação umas com as outras (YAZAN, 2016); c) Bibliográfica, respaldando-se em autores como Dias (2010), Fazenda (2011), Gonçalves (2002; 2006), Leff (2001), Paviani (2008), Quintas (2019), Ruiz, Rodriguez (2020), dentre outros; d) Pesquisa-ação, considerando o objetivo de melhorar a prática dos participantes, a compreensão dessa prática e a situação onde foi produzida. Paralelamente, a pesquisa assegurou a participação dos integrantes do processo (pesquisaores da UnC, professores, alunos da Escola de Educação Básica Professor Olavo Cecco Rigon), assegurou a organização democrática da ação e propiciou o compromisso dos participantes com a mudança. Reitera-se, assim, que a pesquisa-ação educacional é principalmente uma estratégia para o desenvolvimento de professores e pesquisadores de modo que eles possam utilizar suas pesquisas para aprimorar seu ensino e, em decorrência, o aprendizado de seus alunos.

Para Brandão (1985, p. 27),

[...] a finalidade da pesquisa-acão é de favorecer a aquisição de um conhecimento e de uma consciência crítica do processo de transformacão pelo grupo que está vivendo esse processo, para que ele possa assumir, de forma cada vez mais lúcida e autônoma, seu papel de protagonista e ator social.

Diferentemente das pesquisas tradicionais, na pesquisa ação a população não é passiva, participa ativamente do processo. A população consistiu de duas turmas de terceiros anos do ensino médio da Escola de Educação Básica Professor Olavo Cecco Rigon e professores pesquisadores.

A coleta de dados priorizou instrumentos como observação, entrevistas com alunos e comunidade, diário de campo. Transcritos os depoimentos e relatos concentrou-se esforços na análise textual articulando-se com os objetivos propostos pela pesquisa. 


\section{A PROPOSTA}

O desenvolvimento do projeto de intervenção possibilitou a ampliação da interdisciplinaridade em sua perspectiva epistemológica conceitual e prática, fortalecendo a percepção, os conceitos e as práticas da transversalidade. Afinal, o desenvolvimento do projeto se constituiu em esforços teóricos conceituais e práticos da Educação Ambiental. Por certo, também pôde ser compreendido como a mobilização social e o desenvolvimento de atividades teórico-conceituais e práticas que estimularam princípios e valores, a produção e a apropriação do conhecimento, bem como atitudes e práticas concretas sustentáveis que incidiram sobre o meio ambiente.

Considerando o aspecto polissêmico da conceituação de interdisciplinaridade, três definições serão apresentadas para melhor compreensão do termo. Medeiros (2018) diz que

[...] interdisciplinaridade é um conceito que se refere ao processo de ligação existente entre duas ou mais disciplinas, a partir de algo que é comum entre elas. Por isso a interdisciplinaridade propõe a capacidade de dialogar entre as diversas ciências, fazendo entender o saber como um todo, e não como partes fragmentadas.

Michaud (1972 apud FAZENDA, 2011, p. 54), por sua vez, estabelece o conceito de interdisciplinaridade como a

[...] interação existente entre duas ou mais disciplinas. Essa interação pode ir da simples comunicação de ideias à integração mútua dos conceitos diretores da epistemologia, da terminologia, da metodologia, dos procedimentos, dos dados e da organização referentes ao ensino e à pesquisa.

Já no conceber da CAPES (2008, p. 2), a interdisciplinaridade constitui-se num modo de produzir o conhecimento, pois "[...] implica trocas teóricas e metodológicas, geração de novos conceitos e metodologias e graus crescentes de intersubjetividade, visando atender a natureza múltipla de fenômenos com maior complexidade".

A exemplo do termo interdisciplinaridade, também o conceito de multidisciplinaridade assume características polissêmicas. Diferentes autores apresentam conceitos com características distintas, mas com alguma similaridade. Michaud (1972 apud FAZENDA, 2011, p. 67) a descreve como a "[...] gama de disciplinas que se propõem simultaneamente, mas sem fazer aparecer as relações que possam existir entre elas; destina-se a um sistema de um só nível e de objetivos múltiplos, mas sem nenhuma cooperação". Em adição, Paviani (2008, p. 76) designa que a "[...] a multidisciplinaridade pode ser entendida como o estudo, ao mesmo tempo, de um objeto de uma única disciplina por diversas disciplinas".

Historicamente e, tradicionalmente, as escolas desenvolvem atividades pedagógicas em seus espaços convencionalmente denominados de sala de aula. No entanto, a proposta metodológica gerada pelo projeto de intervenção visou a superação do tradicionalismo pedagógico. Por exemplo, propôs estimular os estudantes à realizarem caminhadas e visitação ao rio e ao entorno da Escola; realizarem estudos diferenciados; práticas de produção de tecnologias ecologicamente sustentáveis de aplicabilidade e de replicação, dentre outras atividades. 
No ambiente de desenvolvimento do projeto, alguns movimentos resultaram em ações que geraram impactos nos processos de escoamento, gestão e aproveitamento de águas de chuva de maneira diferenciada. Para tanto, o desafio contemplou a apropriação do conhecimento científico in loco numa micro, sub ou bacia hidrográfica, e, de maneira mais específica, num rio. Ou seja, possibilitou sair da sala de aula, estimular os jovens estudantes a verem, conhecerem, contemplarem, refletirem, e se sensibilizarem com os elementos físicos e humanos do espaço, com maior especificidade as águas do referido espaço visitado. Isso gerou mudanças nas tradicionais formas de pensar, estudar, se relacionar com os recursos naturais e se apropriar de conceitos e conhecimentos.

O outro aspecto da experiência abordou a sensibilização dos docentes e principalmente discentes para a produção de novos materiais didáticos qualificados e diferenciados por meio da utilização de tecnologias sociais (computador, tabletes, câmera fotográfica, câmera filmadora e outros dispositivos). Esses materiais contribuem com o processo de ensino, pesquisa, aprendizagem e apropriação de conhecimentos.

Para a operacionalização do projeto, o Programa de Mestrado em Desenvolvimento Regional da Universidade do Contestado contou com uma equipe pedagógica multidisciplinar, composta por professores das áreas da saúde, ciências da terra, ciências humanas, exatas e aplicadas. De igual modo, os professores da Escola e os ambientalistas voluntários também contribuíram de acordo com suas habilidades e competências.

\section{A OPERACIONALIZAÇÃO}

A operacionalização do Projeto "Conhecer e interagir com e na Bacia hidrográfica da Escola" partiu, pedagogicamente, do desenvolvimento de atividades que contemplassem questões envolvendo o tema gerador, tais como: bacia hidrográfica, gestão das águas, ciclo hidrológico, entre outras. Assim, desde o início estabeleceram-se algumas questões norteadoras: para onde vai a água da chuva que cai no telhado da nossa casa e de nossa escola? Como, por que, quando, onde e quanto chove? Quais os tipos de chuva? Qual é o 'motor' das chuvas? Também se tratou de conteúdos relacionados com o ciclo hidrológico e sua importância na quantidade de água, da história da formação geológica regional na qual se situa o rio Lajeado Sabão, da localização geográfica e/ou cartográfica da bacia hidrográfica.

Outras questões também se apresentaram como norteadoras da investigação, como: quais os tipos ou classificação de bacias? O que é um rio? E um córrego? Como se forma? Quais são os elementos de um rio? O que é uma nascente ou olho d'água? Como identificar as margens de um rio? O que é o leito do rio e como pode apresentar-se? O que é a foz de um rio? O que é uma bacia hidrográfica? O que é um afluente? Qual a relação entre os rios e a história das sociedades humanas? O que é faixa ciliar e qual a sua função? Essas e outras questões norteadoras foram fundamentais para demonstrar a necessidade de se estudar os aspectos físicos da área, bem como pesquisar o processo histórico de ocupação humana do espaço. Além disso, tais questões foram abordadas, relacionadas e estudadas de forma inter e multidisciplinar.

No âmbito dos estudos multidisciplinares apresentados anteriormente, o conhecimento e reconhecimento da fisionomia regional tomou por base as transformações geradas no tempo 
e no espaço; as principais atividades econômicas desenvolvidas; a recuperação da história social e econômica do referido rio e dos rios em geral; o estabelecimento de paralelos históricos: a representação social do rio no passado, contada pelas pessoas de maior vivência (idosas), comparando-a com o significado, ou o que o rio é e representa na atualidade para os moradores do entorno.

Ainda, como estratégia do desenvolvimento do projeto, se operacionalizou uma investigação realizada no cotidiano da vida dos estudantes, pela qual se inquiriu acerca dos sujeitos envolvidos, com questionamentos como: qual o nome do rio que passa mais perto da sua casa? Da sua escola? Da sua localidade? Para que é usado? Qual a largura? Para onde ele segue? Qual o nome do rio principal ou maior que você conhece? Sabe a sua história? Como ele era e como é? Como eram suas margens? Para que era usado e como é hoje (navegação, transporte de cargas ou pessoas, pesca, lazer, geração de energia, lavação de roupa, dessedentar animais, irrigação, ou outros usos)? Como suas águas eram usadas (eram desviadas ou não)? Houve mudança? Por quê? Quais as causas? Há necessidade de melhorar suas águas? Como poderemos fazê-lo?

Para além disso, cabe reconhecer e considerar que as intervenções realizadas na área da bacia hidrográfica, bem como nas demais microbacias e rios, repercute o modo direto e indireto na qualidade e quantidade da água de cada bacia e na relação com os moradores e sujeitos sociais envolvidos. Essas ações na operacionalidade do projeto ocorreram antes, no decorrer das caminhadas ao longo do rio, e após as visitas à microbacia hidrográfica do rio Lajeado Sabão.

\section{RESULTADOS E DISCUSSÃO}

Em síntese, o discorrido neste artigo aborda a questão das águas, os rios e as relações com o ambiente. São enunciados, conteúdos, situações e relações representativas e emergentes. Dessa forma, impõe-se a necessidade de reflexões abrangentes. Mas, para além disso, impõese, também, a necessidade de práticas sustentáveis com os referidos bens naturais.

As águas e os rios são fundamentais para os seres humanos e sua dinâmica social. É reconhecido que os rios marcaram os caminhos seguidos pelos humanos e não humanos. Definiram a localização e sobrevivência de povos e nações. São imbricados com a própria formação sócio-histórica humana e de cada contexto social, político e econômico.

A escassez e poluição das águas superficiais e subterrâneas podem implicar diretamente no comprometimento da qualidade de vida humana, de localidades, comunidades, bem como nas formas de vida animal e até mesmo dificultar o desempenho das atividades econômicas e da própria sustentabilidade em todos os aspectos.

Neste contexto, a experiência desenvolvida estimulou a promoção de boas práticas de preservação ambiental e a adoção de tecnologias sociais de gestão dos recursos hídricos; a criação de um espaço de diálogo entre os diferentes atores, saberes e práticas ambientais que envolvem a Escola; fomentou novas pesquisas e tecnologias inovadoras na área de conservação de recursos hídricos, além da produção diferenciada de material didático pedagógico para 
socialização e divulgação do conhecimento escolar e técnico, vinculados à gestão de recursos hídricos, não apenas regionais, mas para todo o território nacional.

Considera-se que não há um modelo único adequado para todas as situações na promoção de ações educativas socioambientais. Sugeriram-se, também, atividades adequadas à realidade e que suscitaram a participação ativa da comunidade na resolução de seus próprios problemas. Desse modo, em vista da relevância social do processo empreendido, apostou-se no desenvolvimento de intervenções na perspectiva de subsidiar, mediar a operacionalização de propostas que atendessem às necessidades dos educadores, educandos e sociedade em geral, tanto local quanto regional e nacional.

$\mathrm{Na}$ sequência apresentam-se os principais resultados obtidos pelo projeto no que concerne à produção de material didático:

Figura 2 - Livro pedagógico e interativo.

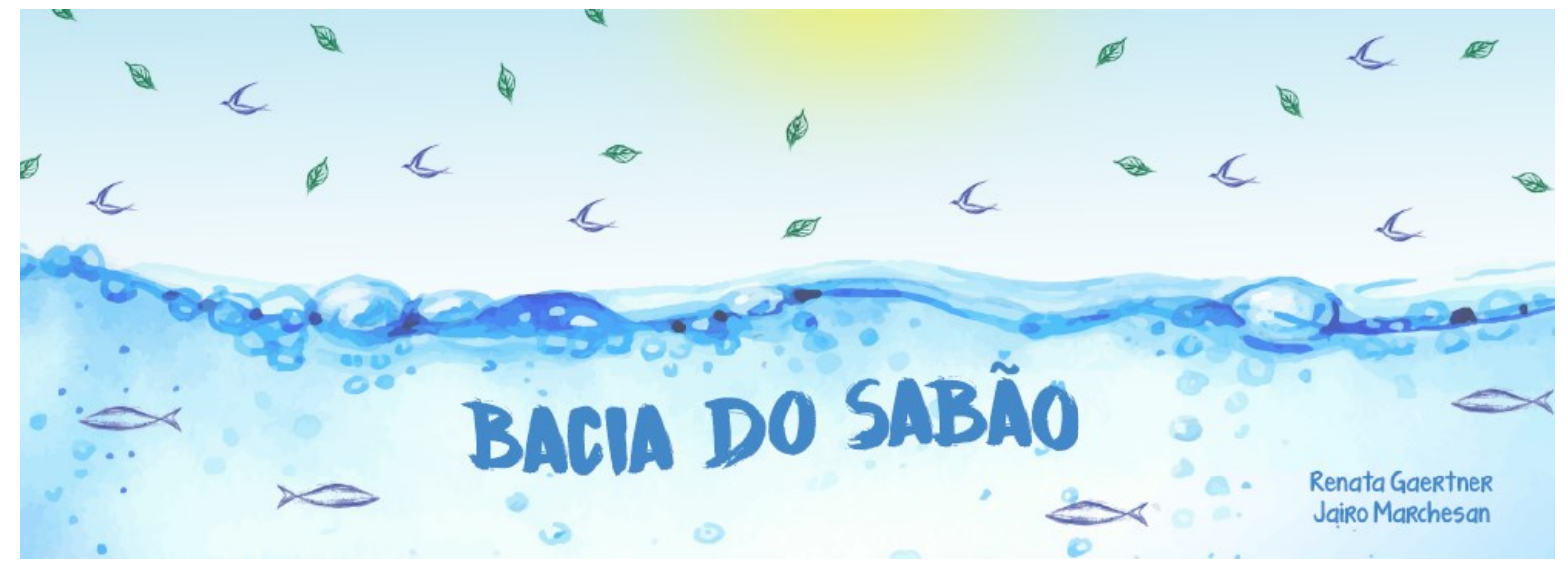

Fonte: Docentes, atores e pesquisadores (2016)

A publicação permite que os leitores compreendam e complementem seus conhecimentos, estimulando-os a pesquisar sobre o tema. Do mesmo modo, o livro possibilita o sujeito a se tornar coautor e escrever a sua história.

Desse modo, a parte externa trata-se de um encarte em forma de dobradura (Figura 3). Nela consta o título: "Nossas bacias \& nossas vidas". Nesse encarte são apresentados os autores e vários conceitos e temas, tais como: conceito de bacia hidrográfica, situação da bacia do Lajeado Sabão, características gerais da bacia, banhados e sua importância para a biodiversidade, modos de obtenção de água superficial e subterrânea e outros. 
Figura 3 - Encarte pedagógico

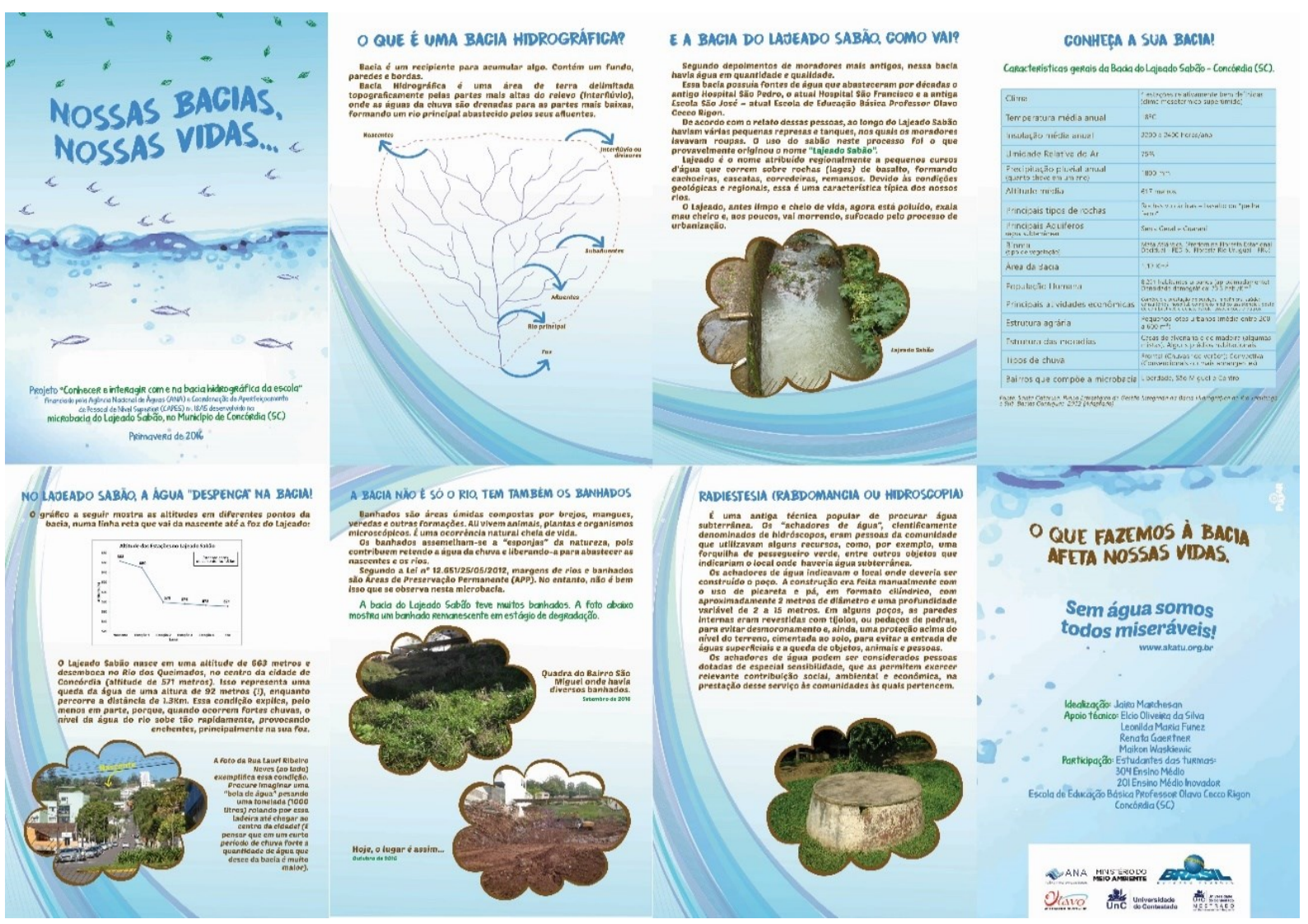

Fonte: Docentes, atores e pesquisadores (2016)

No mesmo encarte, na parte interna (Figura 4), estão contidas iniciativas e proposições. Ou seja, o que cada pessoa pode aplicar como prática de proteção e conservação dos mananciais, como coletar e aproveitar a água da chuva, promover a arborização urbana, reciclagem, construir drenagens para permitir a infiltração da água no solo etc.

No centro do encarte consta uma figura indicando a localização geográfica da Microbacia do Lajeado Sabão. 
Figura 4 - Encarte (parte interna)

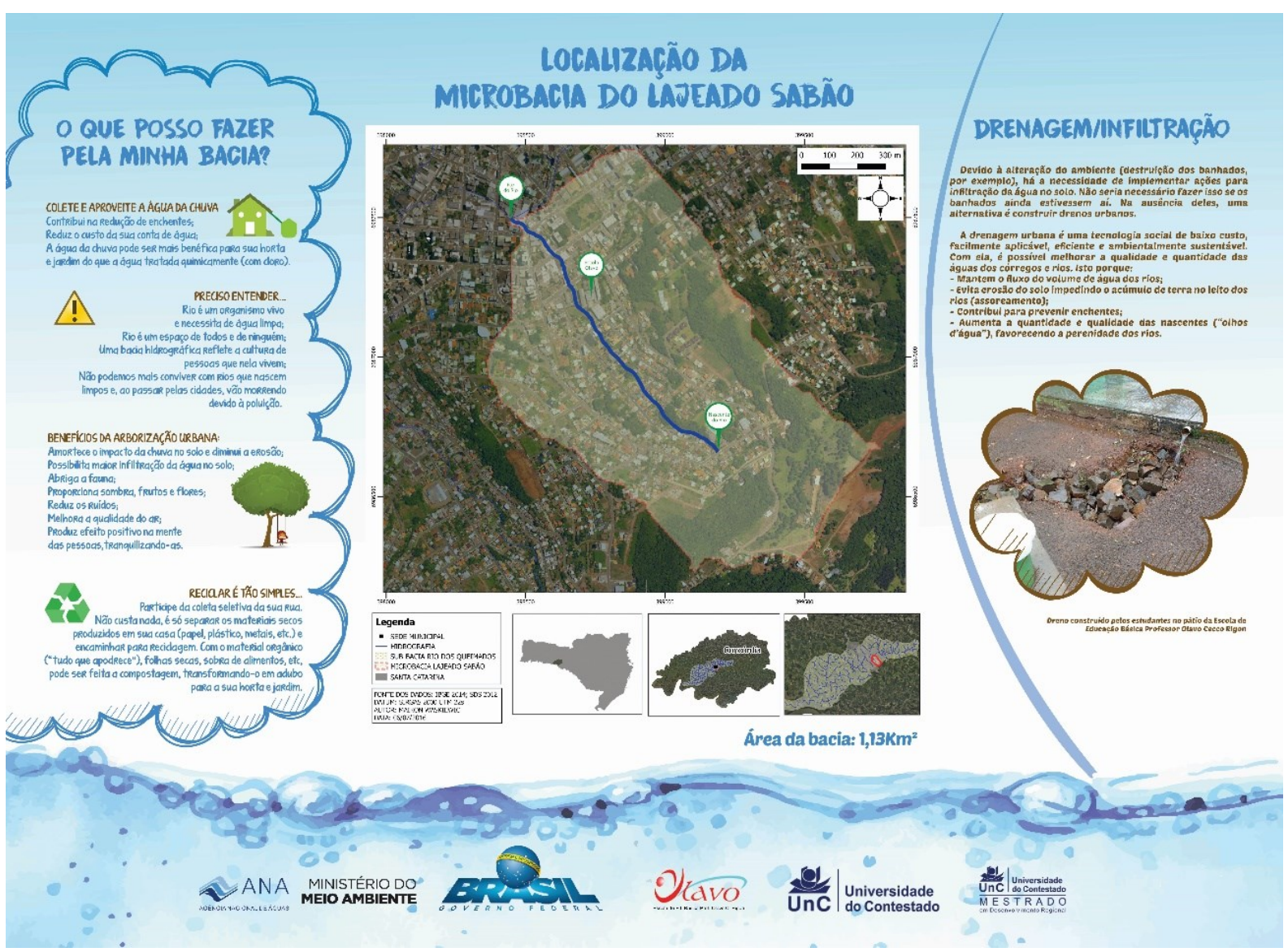

Fonte: Docentes, atores e pesquisadores (2016)

Na Figura 5, abaixo exposta, apresenta-se o Flayer, no qual constam questões que visam estimular as pessoas a refletir sobre a procedência das águas utilizadas cotidianamente e para onde as mesmas (águas servidas) são destinadas. Esse material pode suscitar outros e novos questionamentos.

Como resultado da produção, puderam se constituir novas reflexões, aprendizagens materializando-as em práticas ambientais sustentáveis. 
Figura 5 - Flayer

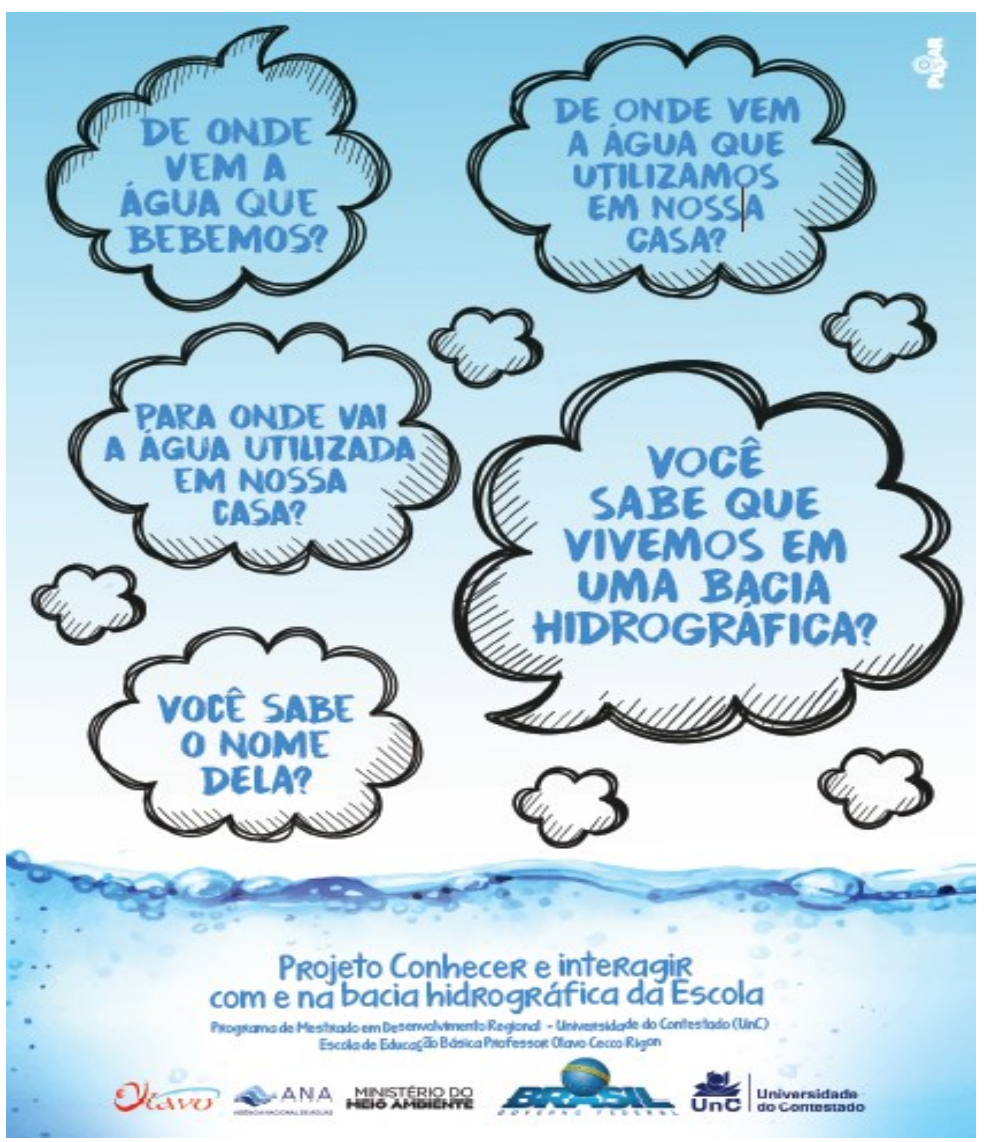

Fonte: Docentes, atores e pesquisadores (2016)

Ademais, foi produzido um dreno no terreno da escola envolvida (Figuras 6 e 7).

Embora essa produção não se apresente em formato tradicional, como livros, cartilhas ou outros, entende-se que a construção de um dreno a fim de captar a água da chuva dos telhados da escola, para conduzi-la por meio das calhas situadas nas abas do prédio, passando por via dos condutores, para o solo, também pode ser considerado material didático pedagógico que representa uma tecnologia social de gestão das águas. Esse sistema evita processos erosivos e assoreamento dos rios, reduz as inundações e facilita o abastecimento dos aquíferos subterrâneos.

Desta forma, assim como o bosque da escola, outros espaços e ações podem se tornar fonte de pesquisa e conhecimento público. Ou seja, "um livro aberto", pleno de possibilidades pedagógicas. 
Figura 6 - Estudantes construindo o dreno no terreno ou espaço da Escola
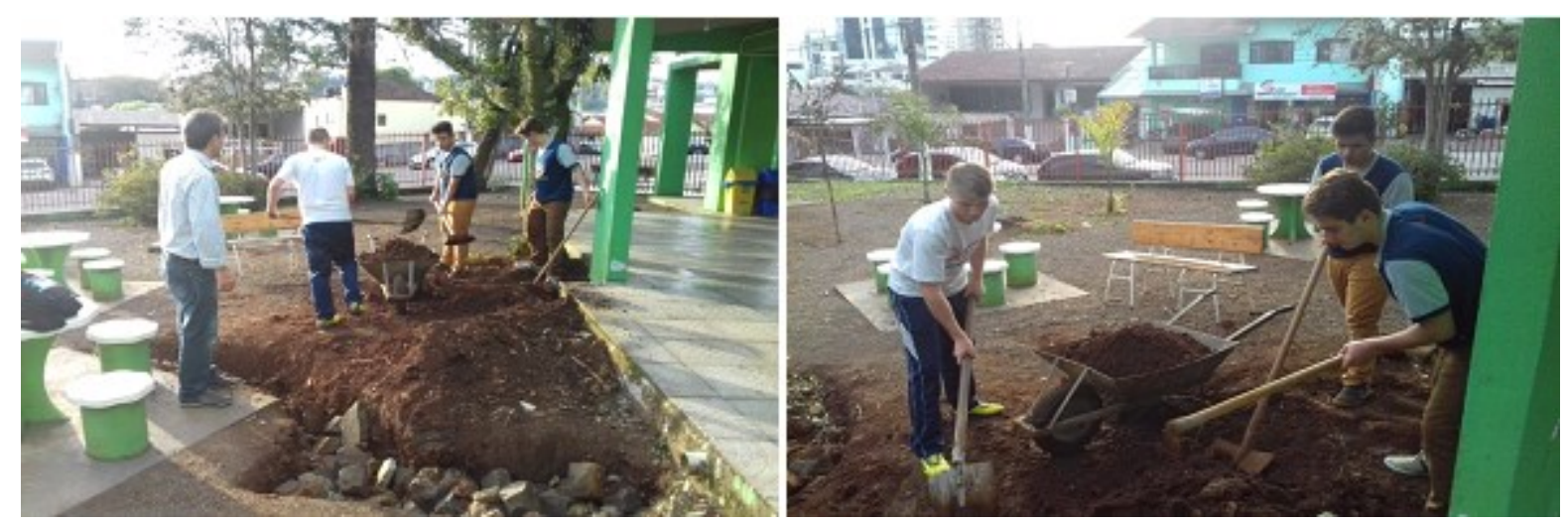

Fonte: Docentes, discentes e pesquisadores (2016)

Figura 7 - Foto que ilustra o ambiente e situa uma das práticas

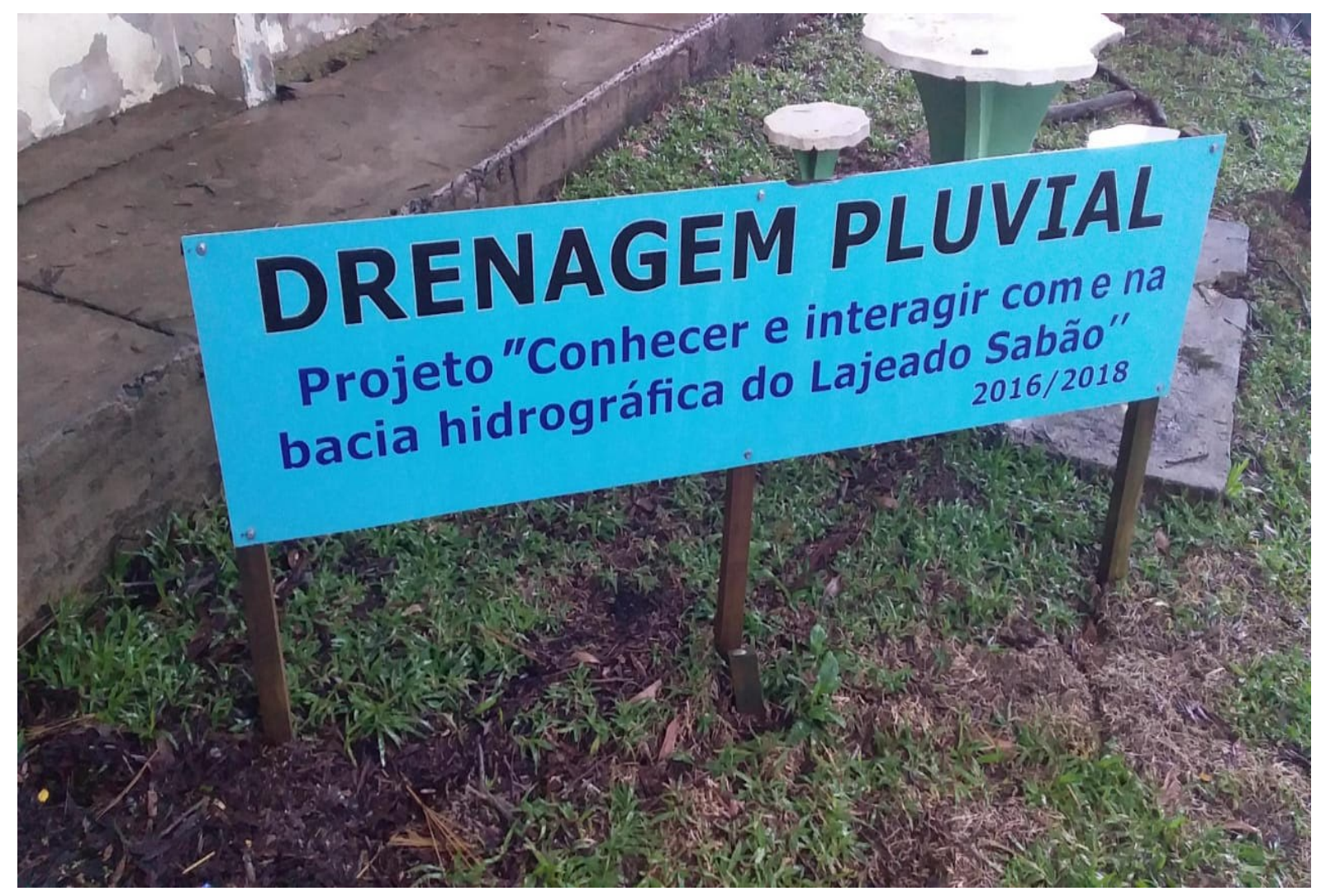

Fonte: Docentes, discentes e pesquisadores (2016)

Outra produção resultante do projeto foi a gravação de um vídeo (disponível em: https://youtu.be/S2klLEphmNI) sobre a concepção, construção e desenvolvimento do Projeto, as relações que se estabelece com as águas e o que se pode e deve-se fazer em prol desses recursos e bens naturais. 


\section{CONSIDERAÇÕES FINAIS}

Entende-se que é importante avaliar projetos propostos e executados, sejam de intervenção ou não, sobre a educação ambiental, pois isso pode contribuir para a realização futuras propostas a serem implementadas, com o intuito de incentivar os processos de execução, gestão e de melhoria dos planejamentos, envolvendo as questões da relação humana com os recursos hídricos e com o meio ambiente em sua totalidade.

O Projeto "Conhecer e interagir com e na bacia hidrográfica da Escola", desenvolvido na Escola de Educação Básica Professor Olavo Cecco Rigon, no município de Concórdia (SC), é considerado de relevância teórica e prática, visto que sua proposta envolveu romper com os muros pedagógicos da escola. Ou seja, contribuiu para desvencilhar-se das tradicionais práticas desenvolvidas nas salas de aula e levar o ensino, a pesquisa e a prática pedagógica científica ao campo.

A realização do projeto oportunizou aos estudantes da Educação Básica reconhecer os espaços físicos da Escola, reconhecer os aspectos ambientais de seu entorno, especialmente a funcionalidade de uma bacia hidrográfica, as relações que os indivíduos e sociedades de determinado local, região e comunidades estabelecem com as águas, as contradições, relações e decorrência com o ambiente. Ao mesmo tempo, promoveu a potencialidade de pensar, propor e realizar uma prática diferenciada em prol do cuidado e da gestão mais adequada dos bens naturais, especialmente das águas.

Como resultado atendeu o propósito de um Edital Nacional de produzir materiais didáticos pedagógicos para a Educação Básica, demonstrando o protagonismo juvenil, o envolvimento intenso do Programa de Mestrado em Desenvolvimento Regional da Universidade do Contestado comprometido com o desenvolvimento regional, e que se apresenta como experiência pedagógica possível também em âmbito nacional.

Neste sentido, entende-se que o Projeto alcançou avanços expressivos, contribuições e/ou benefícios, principalmente possibilidades de intervenção ambiental, que poderão ser replicadas para o contexto da propriedade dos estudantes ou outras situações. Nessa perspectiva, entende-se que os resultados do projeto contribuíram para promoção da qualidade de vida das pessoas e da biota, e, em última instância, para percepções e ações em vista do desenvolvimento regional.

Assim, considera-se que o Projeto alcançou êxito social. Alcançou expressão educacional e prática junto à sociedade local (microbacia municipal). Ainda nessa direção, no campo da educação, conseguiu produzir materiais com capacidade de mobilizar os estudantes e despertar a constituição de novas consciências que poderão resultar em novas, diferentes e qualificadas atitudes e práticas ambientais mais sustentáveis ambientalmente. Afinal, o tema água é atual, necessário, urgente e detém apelo social. 


\section{AGRADECIMENTOS E INFORMAÇÕES}

Agradecemos a Agência Nacional de Águas (ANA) e a Coordenação de Aperfeiçoamento de Pessoal de Nível Superior (CAPES) pela concessão dos recursos por meio do Edital $n^{\circ}$ 18/2015 para a produção de material didático pedagógico a Educação Básica brasileira.

É obrigatória a seção de agradecimentos para trabalhos que tenham recebido recursos de agências de fomento governamentais (FAPESP, CAPES, CNPq, MEC, MCTI, etc.), para aqueles cujos autores tenham recebido bolsas de pesquisa, extensão, mestrado e/ou doutorado, bem como, para aqueles que tenham sido realizados com a autorização de órgãos governamentais (IBAMA, ICMBIO, Secretarias Municipais, etc). Para os demais trabalhos, a seção de agradecimentos é opcional.

Informamos que o projeto foi submetido à aprovação do Comitê de Ética, por contemplar metodologias que envolveram a interação com seres humanos, como entrevistas e observações.

\section{REFERÊNCIAS}

ANA (AGÊNCIA NACIONAL DE ÁGUAS). Lista de termos para o thesaurus de Recursos hídricos da agência nacional de águas. Brasília, DF: ANA, 2014. Disponível em:

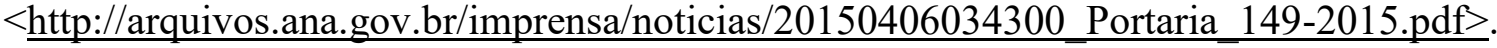
Acesso em: 28 abr. 2020.

BRANDAO, C. R. Repensando a pesquisa participante. São Paulo: Brasiliense, 1985.

BRASIL. Lei no 9.433, de 8 de janeiro de 1997. Institui a Política Nacional de Recursos Hídricos, cria o Sistema Nacional de Gerenciamento de Recursos Hídricos, regulamenta o inciso XIX do art. 21 da Constituição Federal e altera o art. $1^{\circ}$ da Lei ${ }^{\circ} 8.001$, de 13 de março de 1990, que modificou a Lei n 7.990 , de 28 de dezembro de 1989. Disponível em: http://www.planalto.gov.br/ccivil_03/leis/19433.htm. Acesso em: 28 abr. 2019.

BRASIL. Lei $\mathbf{n}^{0}$ 9.795, de 27 de abril de 1999. Dispõe sobre a educação ambiental, institui a Política Nacional de Educação Ambiental e dá outras providências. Disponível em: http://www.planalto.gov.br/ccivil_03/leis/19795.htm. Acesso em: 28 abr. 2019.

BRASIL. Ministério da Educação. Base Nacional Comum Curricular (BNCC). Brasília: Ministério da Educação, 2018. Disponível em: http://portal.mec.gov.br/conselho-nacional-deeducacao/base-nacional-comum-curricular-bncc. Acesso fev. 2020.

BRASIL. Secretaria de Educação Fundamental. Parâmetros Curriculares Nacionais: terceiro e quarto ciclos: apresentação dos temas transversais / Secretaria de Educação Fundamental. Brasília: MEC/SEF, 1998. Disponível em

$<$ http://portal.mec.gov.br/seb/arquivos/pdf/ttransversais.pdf $>$ Acesso em fev. 2020. 
CAPES (COORDENAÇÃO DE APERFEIÇOAMENTO DE PESSOAL DE NÍVEL

SUPERIOR). Interdisciplinaridade como desafio para o avanço da ciência e tecnologia. In.: PHILIPPI JR, A. (org.) Coordenação de área interdisciplinar: catálogo de programas de pós-graduação - mestrado e doutorado. Brasília: CAInter/CAPES, 2008. p. 2-3.

CAPES (COORDENAÇÃO DE APERFEIÇOAMENTO DE PESSOAL DE NÍVEL SUPERIOR). Brasil. Edital ANA-CAPES/DEB n ${ }^{\circ}$ 18/2015. Programa de Apoio à Produção de Material Didático para a Educação Básica - Projeto Água. Diário Oficial da União, Brasília, DF: DOU, 29 set. 2015. Disponível em: $<$ https://www.gov.br/capes/pt-br/centraisde-conteudo/2102015-edital-18-capes-projeto-agua-2015-pdf/view $>$. Acesso em: fev 2020

CARTA DA TERRA. Valores e princípios para um futuro sustentável. Petrópolis, RJ: Gráfica Editora Stamppa, 2004. Disponível em: <https://docplayer.com.br/8958082-Valorese-principios-para-um-futuro-sustentavel.html> Acesso em: 10 fev. 2020.

DIAS, G. F. Educação ambiental: princípios e práticas. 9. ed. São Paulo: Gaia, 2010.

SANTA CATARINA. Currículo base da educação infantil e do ensino fundamental do território catarinense. Florianópolis: Secretaria de Estado da Educação, 2019. Disponível em: file://C:/Users/seven/Downloads/Curr\%C3\%ADculo\% 20Base $\% 20$ Ed.\%20Infantil\%20e\%20Ens. $\% 20$ Fundamental $\% 20 \mathrm{de} \% 20 \mathrm{SC} \% 20$ \%20Forma\%20Final\%20(2).pdf. Acesso: jan. 2019

FAZENDA, I. C. A. Integração e interdisciplinaridade no ensino brasileiro: efetividade ou ideologia. 6. ed. São Paulo: Loyola Jesuítas, 2011.

FLEURY, M. T. L.; WERLANG, S. R. C. Pesquisa aplicada: conceitos e abordagens. In: FUNDAÇÃO GETÚlIO VARGAS. Anuário de Pesquisa 2016-2017. São Paulo: Única Gráfica e Editora, 2016. p. 10-15.

FLORÊNCIO, J. M. Educação ambiental formal no ensino médio para gestão de recursos hídricos: o caso do reservatório Carpina. Orientador: Maria do Carmo Martins Sobral. 2018. 84 f. Dissertação (Programa de Pós-Graduação em Rede Nacional em Gestão e Regulação de Recursos Hídricos) - Universidade Federal de Pernambuco, Recife, 2018.

GONÇALVES, C. W. P. Os (des)caminhos do meio ambiente. São Paulo: Contexto, 2002.

GONÇALVES, C. W. P. A globalização da natureza e natureza da globalização. Rio de Janeiro: Civilização Brasileira, 2006.

LEFF, E. Epistemologia ambiental. São Paulo: Cortez, 2001.

LEONARDI, M. L. A. Educação ambiental e teorias econômicas: primeiras aproximações. In: ROMEIRO, A. R (Org.). Economia do meio ambiente: as teorias políticas e a gestão de espaços regionais. 3. ed. Campinas-SP: UNICAMP-IE, 2001. Disponível em: http://www.bdpa.cnptia.embrapa.br/consulta/busca?b=ad\&id=16843\&biblioteca. Acesso em: jul. 2020

MARCHESAN, J. A questão ambiental na produção agrícola: um estudo sócio-históricocultural no Município de Concórdia (SC). Ijuí: Unijuí, 2003. 
MEDEIROS, A. M. Interdisciplinaridade e Transdisciplinaridade. Sociedade e Política, Parintins, dez. 2018. Disponível em:

$<$ https://www.sabedoriapolitica.com.br/products/interdisciplinaridade-etransdisciplinaridade/> Acesso em: 12 jul. 2020.

NIDELCOFF, M. T. A escola e a compreensão da realidade. São Paulo: Brasiliense, 1986.

PAVIANI, J. Interdisciplinaridade: conceitos e distinções. 2. ed. Caxias do Sul, RS: Educs, 2008.

QUINTAS, J. S. Gestion publique de l'environnement et éducation: pratique de l'éducation à l'environnement critique par l'État brésilien. Droit et cultures, n.78, p. 19-45, 2019.

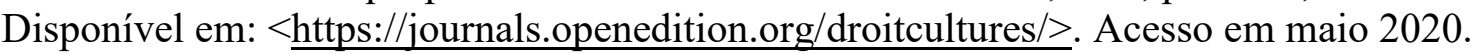

RUZ, I. S.; RODRÍGUEZ, B.A. EI Ciclo Hidrosocial: una propuesta didáctica desde la historia, la geografía, las ciencias sociales y la educación para la ciudadanía. Santiago de Chile: Centro de Comunicación de las Ciencias Universidad Autónoma de Chile, 2020.

Disponível em $<\mathrm{https}$ ://ciencias.uautonoma.cl/hidrosocial/ $\geq$. Acesso jun 2020.

VIEZZER, M. L.; OVALLES, O. (Orgs.). Manual latino-americano de educação ambiental. São Paulo: Gaia, 1994.

WASKIEWIC, M. E. Mapa de localização da Microbacia do Lajeado Sabão. ConcórdiaSC: UnC, 2018.

YAZAN, B. Três abordagens do método de estudo de caso em educação: Yin, Merriam e Stake. Traducao de Ivar Cesar Oliveira de Vasconcelos. Meta: Avaliação, Rio de Janeiro, v. 8, n. 22, p. 149-182, jan. /abr. 2016. 